\title{
UCIECZKI LUDNOŚCI CYWILNEJ Z POŁUDNIOWO- -WSCHODNICH WOJEWÓDZTW RZECZYPOSPOLITEJ W PIERWSZYM ETAPIE POWSTANIA CHMIELNICKIEGO
}

\section{Artur Goszczyński}

http://orcid.org/0000-0002-6643-5416

Uniwersytet Przyrodniczo-Humanistyczny w Siedlcach

\author{
ABSTRACT \\ REFUGEES FROM SOUTH-EASTERN PROVINCES OF THE POLISH- \\ LITHUANIAN COMMONWEALTH DURING THE FIRST STAGE \\ OF THE CHMIELNICKI UPRISING
}

The uprising ignited by Bohdan Chmielnicki had a multidimensional effect on the Polish-Lithuanian Commonwealth. One of its consequences was the migration of population forced by Cossaks' actions. The gentry inhabiting the southeastern parts of the country had to flee inland fearful for their lives. Jews, who were a group prone to being persecuted by Cossacks, acted in a similar way. Refugees from the Ukrainian provinces first fled to the neighbouring city fortresses which, however, capitulated under the siege of the rebels. People who survived the slaughter, usually carried out by the Cossacks, tried to reach the central part of the country hoping to escape the rebels' sabres and spring guns.

Keywords: Chmielnicki uprising, Cossacks, the Polish-Lithuanian Commonwealth in $17^{\text {th }}$ century, Ukrainian gentry, exiles.

Słowa kluczowe: Powstanie Chmielnickiego, Kozacy, Rzeczpospolita Obojga Narodów w XVII wieku, szlachta ukraińska, egzulanci.

Powstanie Chmielnickiego było jednym z newralgicznych momentów w dziejach Rzeczypospolitej. Kozacka rebelia doprowadziła do znacznego osłabienia pozycji polsko-litewskiego państwa w połowie XVII wieku, co sprowokowało kraje ościenne do agresywnych działań naruszających jego integralność terytorialną ${ }^{1}$.

${ }^{1}$ W. Tomkiewicz, Kozaczyzna ukrainna, Lwów 1939, s. 84; Z. Wój cik, Dyplomacja polska w okresie wojen drugiej połowy XVII wieku (1648-1699) [w:] Historia dyplomacji polskiej, t. 2: 1572 1795, red. Z. Wój cik, Warszawa 1982, s. 167.

Adres do korespondencji: artur.goszczynski@op.pl 
Polityczne konsekwencje buntu na Ukrainie nie ulegają wątpliwości, co znajduje odzwierciedlenie w licznych pracach historyków ${ }^{2}$. Nie można jednak zapominać także o znaczeniu tych wydarzeń dla ludności cywilnej, która z obawy o własne życie często podejmowała desperackie próby ucieczki przed Zaporożcami. Badacze dziejów dostrzegają skalę tego zjawiska, jednakże ze względu na dość lakoniczne wzmianki w źródłach często ograniczają się do traktowania go w sposób ogólnikowy. Tymczasem, na podstawie bogatej korespondencji, pamiętników oraz kronik, problem uchodźstwa z ogarniętej powstaniem Ukrainy można przedstawić nieco dokładniej $^{3}$. Nie da się jednak ukryć, że w źródłach częściej napotkać można barwne opisy kozackich okrucieństw aniżeli szczegółowe informacje o samych ucieczkach czy też postawach cywilów wobec rozgrywających się wydarzeń.

Kluczowe dla rozwoju rebelii z 1648 roku były pierwsze starcia Kozaków z wojskiem Rzeczypospolitej nad Żółtymi Wodami i pod Korsuniem, w wyniku których armia koronna de facto przestała istnieć, zaś dowodzący nią hetmani dostali się do tatarskiej niewoli ${ }^{4}$. Powstańcom niewątpliwie sprzyjała także śmierć Władysława IV, który dokonał żywota 20 maja 1648 roku w Mereczu. Zgon monarchy był dodatkowym wstrząsem dla państwa, które wobec bitewnych klęsk potrzebowało silnego przywództwa ${ }^{5}$. Bezkrólewie wzmacniało buntowników, Chmielnicki nie lekceważył jednak osłabionej Rzeczypospolitej, która pomimo klęsk nie utraciła całkowicie potencjału militarnego, nadal drzemiącego w twierdzach mogących skutecznie hamować rozwój powstania. Z pewnością musiał on również zakładać, że do walki włączą się przedstawiciele magnaterii ukrainnej, dysponujący prywatnymi wojskami ${ }^{6}$. W związku z tym po korsuńskim zwycięstwie przywódca rebelii przejawiał dużą ostrożność - nie podejmował pochopnych działań militarnych, dostrzegając konieczność poprawy organizacji swych wojsk i ich zaopatrzenia oraz potrzebę wysondowania stanowiska państw ościennych wobec wydarzeń w Rzeczypospolitej, przede wszystkim Moskwy?

Do pierwszych napaści Kozaków na ludność cywilną doszło zapewne zaraz po zajęciu przez nich Zaporoża na początku 1648 roku$^{8}$, po bitwie korsuńskiej stały się

${ }^{2}$ Przegląd literatury przedmiotu dotyczącej powstania Chmielnickiego przedstawia I. Gavryliuk, Niewygrana wojna. Sztuka wojenna Bohdana Chmielnickiego i innych dowódców kozackich w latach 1648-1651, Oświęcim 2019, s. 12-16.

${ }^{3} \mathrm{Z}$ uwagi na ramy objętościowe artykułu oraz jego przeglądowy charakter konieczne było dokonanie selekcji źródeł. Szersze badania nad problemem zawartym w temacie należałoby w związku z tym uzupełnić o materiały rękopiśmienne (w tym przede wszystkim akta sądów grodzkich funkcjonujących na terenie ogarniętym powstaniem) oraz pominięte tutaj dokumenty znajdujące się w wydanych drukiem zbiorach źródeł.

${ }^{4}$ W. Kucharski, Rozbicie armii koronnej $w$ działaniach wojennych 1648 r., „Studia z Dziejów Wojskowości" 2015, t. 4, s. 70, 75.

${ }_{5}$ A.B. Pernal, Rzeczpospolita Obojga Narodów a Ukraina. Stosunki dyplomatyczne $w$ latach 1648-1659, thum. R. Urbański, Kraków 2010, s. 43.

${ }^{6}$ W. Bi ernacki, Żólte Wody - Korsuń 1648, Warszawa 2004, s. 183.

${ }^{7}$ Ibidem; L. S voboda, Vztahy Bohdana Chmelnického a Moskvy v letech 1648-1649, „Sborník Prací Filozofické Fakulty Brnénské Univerzity. Studia Minora Facultatis Philosophicae Universitatis Brunensis" 2001, C 48, s. 140-141.

${ }^{8}$ В.А. Смолій, В.С. С теп ан ко в, Богдан Хмельницький, Київ 2013, s. 66-68. 
one zaś stałym elementem działań mołojców. Dowiodły tego już pierwsze tygodnie po starciu, podczas których dopuszczali się oni licznych mordów na szlachcie oraz Żydach ${ }^{9}$. Warto wspomnieć, że gorliwie wspomagali ich w tym wypiszczycy oraz okoliczni chłopi, gotowi skozaczyć się w imię zdobycia łatwych łupów oraz wzięcia dziejowej sprawiedliwości na herbowych i starozakonnych ${ }^{10}$. W relacjach pogranicznych wojewodów moskiewskich ${ }^{11}$ oraz w niektórych latopisach wśród głównych przyczyn mordowania ludności cywilnej wymieniano motywy religijne, to jest odwet za szerzenie i narzucanie siłą katolicyzmu, represjonowanie cerkwi czy godzące w prawosławie zawarcie unii brzeskiej ${ }^{12}$. Do tego należy dodać uchwalenie w 1638 roku restrykcyjnej konstytucji ograniczającej swobody kozackie, wprowadzonej po stłumieniu powstań pod wodzą Pawła Pawluka oraz Karpo Skidana, Dymitra Huni i Jacka Ostranicy ${ }^{13}$. Zaporożcy uskarżali się także na samowolę starostów i dzierżawców, utrzymując, że ci zawłaszczają sobie ich majątki, bezprawnie osadzają w więzieniach i mordują ${ }^{14}$.

9 Jakuba Michałowskiego wojskiego lubelskiego a później kasztelana bieckiego Księga pamiętnicza, wyd. A.Z. Helc el, Kraków 1864, s. 25.

${ }^{10}$ Акты, относящиеся к истории Южной и Западной России, собранные и изданные Археографическою комиссиею, т. 3: 1638-1657, ред. Г.Ф. Кар п о в, Санкт-Петербург 1861, s. 216. Według Janusza Kaczmarczyka masowe przyłączanie się chłopów do oddziałów powstańczych było jednym z powodów wstrzymania działań przez Chmielnickiego, który musiał mieć na względzie, że kozaczące się masy mogą wymknąć się spod kontroli. J. Ka c zmarc zyk, Bohdan Chmielnicki, Wrocław-WarszawaKraków 1988, s. 53. „Jakoż każdy chłop albo zabił, albo wygnał w jednej sukni z duszą i dziećmi Pana swego...". Jakuba Michałowskiego..., s. 35.

${ }^{11}$ Źródła tej proweniencji należy traktować ze szczególną ostrożnością, albowiem autorzy relacji w żaden sposób nie weryfikowali zasłyszanych informacji i bezkrytycznie przekazywali je na Kreml.

12 W. Kochow ski, Annalium Poloniae ab obitu Vladislai IV. Climacter Primus, Cracoviae 1683, s. 25-26; Акты, относящиеся к истории Южной и Западной России..., s. 216; Літопис Самовидия, підг. Я.І. Дз и ра, Київ 1971, s. 51. Wagę motywów religijnych w powstaniach kozackich potwierdzają badania Mariusza Roberta Drozdowskiego. M.R. Drozdowski, Religia i Kozaczyzna zaporoska w Rzeczypospolitej w pierwszej polowie XVII wieku, Warszawa 2008, s. 175-205; idem, My o nas i o innych. Szlachta Rzeczypospolitej wobec Kozaczyzny zaporoskiej w latach 1648-1659, Białystok 2018, s. $107-122$.

${ }_{13}$ Ordynacya wojska zaporowskiego regestrowego, w stużbie Rzeczypospolitej będacego [w:] Volumina Constitutionum, t. 3: 1611-1640, vol. 2: 1627-1640, wyd. S. Grodziski, M. Kwiecień, A. Karabowicz, Warszawa 2013, s. 312-314; W. Tomkiewicz, Ograniczenie swobód kozackich w roku 1638, „Kwartalnik Historyczny”, R. 44, 1930, t. 1, z. 2, s. 125-175; A. B o r ow i a k, Kozaczyzna w przededniu powstania Bohdana Chmielnickiego (1635-1648) [w:] Epoka „Ogniem i mieczem” we współczesnych badaniach historycznych, red. M. N a g i els k i, Warszawa 2000, s. 35-36; K. Ło pate cki, Disciplina militaris w wojskach Rzeczypospolitej do połowy XVII wieku, Białystok 2012, s. 279-280.

14 В.О. Щербак, Антифеодальні рухи на Україні напередодні визвольної війни 1648-1654 pp., Київ 1989, s. 91; Документи Богдана Хмельницького 1648-1657, упор. І. Крипякевич, I. Бут ич, Київ 1961, s. 39. Nie należy przy tym przeceniać negatywnego wpływu szlachty przybyłej z Korony na teren województw ukrainnych. Według ustaleń Henryka Litwina wśród kresowych właścicieli ziemskich jej przedstawiciele stanowili bowiem zaledwie nieco ponad 10\%. H. Litw in, Naphyw szlachty polskiej na Ukraine 1569-1648, Warszawa 2000, s. 161; M. Nagie1ski, Ukraińcy [w:] Pod wspólnym niebem. Narody dawnej Rzeczypospolitej, red. M. Kopczyń ski, W. Tyg i l lski, Warszawa 2010, s. 64-65. 
Kozacy czuli się związani z Rzecząpospolitą, mieli świadomość swoich zasług dla państwa oraz własnej siły ${ }^{15}$. Stosowanie wobec nich przemocy, lekceważenie dążeń do uzyskania przywilejów i blokowanie możliwości czynnego udziału w życiu politycznym prowadziło do narastania poczucia zniewolenia, co w konsekwencji zniechęcało do wiernego trwania przy Rzeczypospolitej, rozbudzało nienawiść do szlachty i popychało Zaporożców do otwartego buntu ${ }^{16}$. Nie bez znaczenia był przy tym fakt, że miało to miejsce w czasie wzrostu świadomości narodowej w łonie Kozaczyzny $^{17}$ - czynnika niemal powszechnie negowanego przez panów braci ${ }^{18}$. Pobudki tożsamościowe, przeplatając się z ekonomicznymi, społecznymi i religijnymi motywami, stworzyły bardzo niebezpieczną mieszankę. Jak twierdzi Wiktor Brechunenko, konflikt prywatny Bohdana Chmielnickiego z podstarościm czehryńskim Danielem Czaplińskim, uznawany za bezpośrednią przyczynę powstania z $1648 \mathrm{roku}$, był tylko zapalnikiem dla istniejącej masy krytycznej, na kozacki bunt zanosiło się bowiem już od dłuższego czasu' ${ }^{19}$.

Sposób zarządzania przez szlachtę majątkami na południowym wschodzie Rzeczypospolitej przekładał się do pewnego stopnia na nienawiść mołojców do Żydów, która znajdowała swój upust podczas kolejnych rebelii ${ }^{20}$. Przyczyną tego była gospodarcza rola wyznawców religii mojżeszowej na tym obszarze ${ }^{21}$. Jako dzierżawcy podatków, karczem czy ceł często występowali oni w stosunku do miejscowej ludności w charakterze egzekutorów należności, co bynajmniej nie przysparzało im jej sympatii ${ }^{22}$. Chmielnicki w otwarty sposób wyraził to w liście do marszałka nadwornego

${ }^{15}$ T. Chynczewska-Hennel, Świadomość narodowa szlachty ukraińskiej $i$ Kozaczyzny od schytku XVI do połowy XVII w., Warszawa 1985, s. 142-143.

16 Я. Федорук, Зовнішньополітична діяльність Богдана Хмельнищького і формування його політичної програми (1648 - серпень 1649 рр.), Львів 1993, s. 7-8, 17; M.R. Drozdow ski, „, Со zа czasy!... Chamy taki miód piją! Boże, Ty to widzisz i nie grzmisz?”. O deprecjacji Kozaków przez szlachtę Rzeczypospolitej w okresie powstania Chmielnickiego, „Annales Universitatis Mariae Curie-Skłodowska Lublin - Polonia. Sectio F” 2018, vol. 78, s. 66-67.

17 В.А. С молі й, В.С. С те п ан к о в, Украӥнська державна ідея XVII-XVIII століть: Проблеми формування, еволюції, реалізації, Київ 1997, s. 22.

${ }^{18}$ W. Li i iń ski, Stanisław Michat Krzyczewski. Z dziejów walki szlachty ukraińskiej w szeregach powstańczych pod wodza Bohdana Chmielnickiego, Kraków 1912, s. 23. M.R. Drozdow sk i, My o nas i o innych. Szlachta Rzeczypospolitej wobec Kozaczyzny zaporoskiej w latach 1648-1659, Białystok 2018, s. 32.

19 В. Брехуненко, Богдан Хмельницький, Київ 2007, s. 17.

${ }_{20}$ М. Го л ін с ь к й, Silva Rerum (1648-1665), ч. 1: (1648-1649), упор. О. З а я ць, Я. Фе дорук, Київ 2019, s. 140; Jawein Mecula, t.j. Bagno głębokie, kronika zdarzeń z lat 1648-1652 napisana przez Natana Hannowera z Zastawia $i$ wydana po raz pierwszy $w$ Wenecyi $w$ r. 1656, oprac. M. Bałaban, [w:] Sprawy i rzeczy ukraińskie. Materyaly do dziejów kozaczyzny i hajdamaczyzny, wyd. F. Rawita-Gawroński, Lwów 1914, s. 23; A.J. Rolle, Żydzi na kresach, „Przewodnik Naukowy i Literacki. Dodatek do Gazety Lwowskiej”, R. 5, 1877, s. 34-35.

${ }^{21}$ M. Cieśla, Żydzi a Rzeczpospolita [w:] My i oni. Spoleczeństwo nowożytnej Rzeczypospolitej wobec państwa, red. W. Kri g g e i s en, Warszawa 2016, s. 260-262.

22 E. Ringelblu m, Dzieje zewnętrzne Żydów w dawnej Rzeczypospolitej [w:] Żydzi w Polsce odrodzonej. Działalność społeczna, gospodarcza, oświatowa i kulturalna, t. 1, red. I. S c hiper, A. Tartak ow er, A. Hafftk a, Warszawa 1932, s. 56; J. S cha11, Rok 1648 i kniaź Jeremi Wiśniowiecki w świetle wspótczesnych historyków żydowskich, „Miesięcznik Żydowski”, R. 4, 1934, s. 265. 
koronnego Adama Kazanowskiego, nadmieniając, że starozakonni czynili nad Kozakami „wielkie zbytki”"23. Z kolei w kronice rajcy kazimierskiego Marcina Golińskiego można nawet odnaleźć opinię, że przyczyną buntu było nadmierne uprzywilejowanie Żydów, którzy posiadali większe prawa od Zaporożców, zezwalające im na przykład na warzenie piwa i palenie gorzałki ${ }^{24}$. Zarzuty te były stałym elementem kozackiej propagandy uzasadniającej wybuch powstania z $1648 \mathrm{roku}^{25}$. Nie zmienia to jednak faktu, że już samo wyznanie czcicieli Jahwe dawało asumpt do nienawiści, w Kościele prawosławnym bowiem głęboko zakorzenione było przekonanie o ponoszeniu przez Żydów winy za ukrzyżowanie Chrystusa ${ }^{26}$. Ponadto odmienność języka i obyczajów mogła dodatkowo wzmagać do nich niechęć i wrogość jako do obcych.

Pierwsze tygodnie powstania były tragiczne w skutkach dla cywilów zamieszkujących południowo-wschodnie obszary Rzeczypospolitej. Chmielnicki po rozbiciu armii koronnej rozesłał Kozaków po grodach, siołach i wsiach, aby przejmowali w nich władzę oraz mordowali znajdujących się tam Polaków i Żydów ${ }^{27}$. Rzekomo niejaki Jan Turkowski miał słyszeć, jak ów rozkazał, ,,aby żadnego katolika i imienia katolickiego nie zostawało" ${ }^{28}$. Niezależnie od tego działania buntowników dotykały różnych grup ludności, bez względu na status społeczno-majątkowy czy wyznanie. Jak bowiem pisze Mikołaj Jemiołowski:

Slachtę ukraińską w domach swych bezpiecznie siedzącą wraz wszędzie przez swoich swywolników z żonami i z dziećmi znosił i niesłychanym morderstwem mordował. Kościoły po pogańsku profanował, łupił, niektóre palić kazał, księżą tyrańsko zabijał, nawet i grobom umarłych nie przepusczano, ale i nad martwymi pastwiono się. Owszem na ubogich wieśniaków, którzykolwiek katolikami zwali się, nie było respektu, jednakowo wszystkich ubogich i bogatych okrutnie i tyrańsko zabijano ${ }^{29}$.

${ }^{23}$ Документи Богдана Хмельницького..., s. 39.

${ }^{24}$ М. Гол ін с ьк и й, Silva Rerum (1648-1665), s. 137.

${ }^{25}$ Jakuba Michałowskiego..., s. 88-89. Krytyka gospodarowania przez szlachtę majątkami na południowym wschodzie Rzeczypospolitej za pośrednictwem Żydów stała się z czasem istotnym elementem kozackiej propagandy. Widać to dobrze na przykładzie kroniki arabskiego podróżnika Piotra z Aleppo, w której znajduje się m.in. wzmianka o starozakonnych dopuszczających się gwałtów na córkach i żonach mołojców. Ukraina w połowie XVII wieku w relacji arabskiego podróżnika Pawła, syna Makarego z Aleppo, wyd. M. Kow als k a, Warszawa 1986, s. 22.

${ }^{26}$ E. Kocój, Światynie, postacie, ikony. Malowane cerkwie i monastyry Bukowiny Poludniowej w wyobrażeniach rumuńskich, Kraków 2006, s. 355-361.

27 Воссоединение Украины с Россией. Документы и материалы в трех томах, т. 2: Освободительная война украинского народа и борьба за воссоединение с Россией 1648-1651 годы, сост. П.П. Гузенко, М.К. Козыренко, А.П. Лола, И.Л. Бутич, М.Г. Репецкая, Москва 1953, s. $37-38$.

28 Джкерела з історії Національно-визвольної війни украӥнського народу 1648-1658 рр., т. 1: 1648-1649 pp., упор. Ю. М и ц и к, Київ 2012, s. 227.

${ }^{29}$ M. J e mi oło w sk i, Pamiętnik dzieje Polski zawierający (1648-1679), oprac. J. Dzię gi elew ski, Warszawa 2000, s. 47-48. Analizując to źródło, należy mieć na uwadze, że powstało ono ok. cztery dekady po wybuchu powstania Chmielnickiego, a jego autor, ceniony przez wielu historyków za względny obiektywizm, opisując sytuację na Ukrainie, wyraźnie przejawia antykozackie stanowisko. M. B a uer, Mikołaj Jemiołowski: Historyk czy pamiętnikarz? O literackości pamiętnika z czasów wojen drugiej połowy XVII wieku, „Acta Universitatis Lodzensis. Folia Litteraria Polonica” 2006, t. 8, s. 87-106. 
Do tych działań thumnie dołączali okoliczni chłopi, którzy po latach ucisku feudalnego ochoczo się kozaczyli ${ }^{30}$. Tatarzy wspierający Zaporożców rozpuszczali zaś zagony celem chwytania jasyru ${ }^{31}$.

Jak wynika z zachowanej korespondencji, część ludności cywilnej podjęła ucieczkę jeszcze przed bitwą nad Żółtymi Wodami. Pisarz polny koronny Andrzej Koniecpolski pod koniec kwietnia z niejakim zdumieniem odnotował, że z obawy przed Kozakami opuszczano nawet miasto Bar i okoliczne miejscowości, nad którymi górował mocno ufortyfikowany zamek ${ }^{32}$. Zanim jednak rebelia przetoczyła się przez Podole, zmagać musieli się z nią mieszkańcy województw kijowskiego i czernihowskiego. Według relacji Łukasza „Głucha” Żółkiewskiego, tamtejsze miasta były naonczas ,pełniusieńskie od szlachty i księży”"33. Nie zawsze jednak uciekinierzy byli w stanie dotrzeć za bramy na czas. Przykładowo, grupa szlachcianek uchodzących z dziećmi do Czernihowa poniosła straszną śmierć z ręki napotkanych w drodze Kozaków, którzy „pobrawszy je wszystkie, w studnie powrzucali i kamieńma a ziemią przywalili" ${ }^{34}$. Schronienie za murami było jednym ze sposobów na ratowanie życia, szybko jednak okazało się, że nawet dobrze ufortyfikowane miasta nie dawały gwarancji bezpieczeństwa. Buntownikom szybko poddał się chociażby Czernihów i sąsiadujące z nim miasta, „wydając im szlachtę katolików oraz Żydów” ${ }^{35}$. Należy jednak w tym miejscu zaznaczyć, że w wielu przypadkach czynnikiem decydującym o wejściu Kozaków za bramy nie była jakość umocnień, a postawa obrońców i mieszkańców danego ośrodka. Zaporożcy bowiem, nie będąc w stanie zdobyć miasta szturmem, wchodzili w układy z broniącymi go mieszczanami i chłopami ruskiego pochodzenia, przekonując ich, że w zamian za wydanie Żydów zachowają pozostałych przy życiu. Faktycznie zaś po wkroczeniu za mury rozpoczynali regularny $\operatorname{mord}^{36}$. Po zajęciu miasta łupiono i palono także okoliczne osady, zabijając przy tym lub biorąc $w$ niewolę zamieszkujących je chłopów ${ }^{37}$. Wedle informacji posiadanych przez wojewodę bracławskiego Adama Kisiela właśnie za sprawą takich postaw gminu bez walki zostało poddanych wiele zamków i miejscowości ${ }^{38}$. W aktach grodzkich można także odnaleźć informacje o herbowych wchodzących w konszachty z rebeliantami. Zazwyczaj takie jednostki inspirowały mołojców do napadu na poszczególne ośrodki lub konkretne osoby, a następnie partycypowały w podziale

${ }^{30}$ Акты относящіеся к исторіи Южной и западной Россіи..., s. 211.

${ }^{31}$ T. Józefowicz, Kronika miasta Lwowa od roku 1634 do 1690 obejmująca w ogólności dzieje dawnej Rusi Czerwonej a zwłaszcza historya arcybiskupstwa lwowskiego w tejże epoce, wyd. M. Piwocki, Lwów 1854, s. 95.

32 Джерела..., s. 35.

33 Jakuba Michatowskiego..., s. 35.

${ }_{34}$ М. Голінський, Silva Rerum (1648-1665), s. 110.

${ }^{35}$ Ibidem.

${ }^{36}$ Ibidem, s. 140-141.

37 Jakuba Michałowskiego..., s. 170-171.

${ }^{38}$ Ibidem, s. 27. 
łupów. Ludzie ci często sami inicjowali współpracę z buntownikami, zakładając, że cała wina za mordy i grabieże spadnie na Kozaków ${ }^{39}$.

Przedstawicieli szlachty zabijano niezależnie od pochodzenia czy pełnionych urzędów (najpewniej samo posiadanie herbu, wyznanie czy też posługiwanie się językiem polskim było dostatecznym powodem, aby ponieść śmierć z ręki buntowników $)^{40}$. Dramatyczny obraz tych wydarzeń skreślił w swoim latopisie Joachim Jerlicz. Można w nim odnaleźć informacje o ucieczce wojewody kijowskiego Janusza Tyszkiewicza z okolic Berdyczowa oraz szlachcie kijowskiej, która uchodziła na zachód, porzucając swój dobytek na pastwę rebeliantów. Opuszczone domostwa były grabione przez buntowników. Ci, którzy nie zdążyli umknąć ze swych siedzib, nierzadko byli brutalnie mordowani. Taki los spotkał między innymi Aleksandra Niemirycza oraz rażonego paraliżem chorążego kijowskiego Teodora Jelca ${ }^{41}$. Wedle latopisu Samowydca już po kilku tygodniach powstania ,aż po Dniestr żadnego Żyda nie zostało, a żony szlacheckie stały się żonami kozackimi” ${ }^{42}$. Ci, których Zaporożcy oszczędzili, stawali się żywym towarem i jako taki byli przez nich przekazywani Tatarom ${ }^{43}$. Warto przy tym wspomnieć, że najbardziej wartościowi dla ordyńców byli „młodzi chłopcy, którzy głowę po polsku golili”44. Dowodem desperacji był fakt, że niektórzy dobrowolnie szli w jasyr, przedostając się do tatarskiego obozu. Czynili tak na przykład Żydzi, którzy spodziewali się trafić na targ niewolników do Konstantynopola, gdzie mogliby zostać szybko wykupieni przez swoich braci w wierze. Ponadto znane są przykłady starozakonnych, którzy usiłowali zachować życie, deklarując przyjęcie wiary prawosławnej ${ }^{45}$.

Rozważając o ucieczkach ludności cywilnej w pierwszych tygodniach powstania Chmielnickiego, nie sposób pominąć działań powziętych przez wojewodę ruskiego księcia Jeremiego Wiśniowieckiego. W połowie maja znajdował się on ze swoim prywatnym wojskiem w okolicach Perejasławia, gdzie oczekiwał na rozkazy od hetmanów. Otrzymawszy wiadomość o pogromie armii koronnej, uświadomił sobie, że grozi mu odcięcie od Rzeczypospolitej oraz okrążenie przez siły powstańców ${ }^{46}$. W związku z tym postanowił szybko opuścić Zadnieprze, podejmując przy tym próby ratowania miejscowej ludności. Magnat rozsyłał informacje do zadnieprzańskich miasteczek, przede wszystkim położonych w jego własnych dobrach, aby ich mieszkańcy ściągali pod jego opiekę. Jak odnotował Bogusław Kazimierz Maskiewicz: „idzie przecie dalej książę z wojskiem, którego mogło być 6000, ale

${ }^{39}$ Материяли до істориї Галичини, т. 2: Акти з р. 1649-1651, упор. С. Том а ш і в с ь и й, Лвов 1901, s. 88, 93.

40 Джерела..., s. 130

${ }^{41}$ Latopisiec albo kroniczka Joachima Jerlicza, wyd. K.W. W ój ci c k i, Warszawa 1853, s. 68-69.

42 Літопис Самовидия..., s. 52.

43 Акты относящіеся к исторіи Южной и западной Россіи..., s. 236; A.S. R a dzi w iłł, Pamiętnik o dziejach w Polsce, t. 3: 1647-1656, oprac. A. Przy boś, R. Żelew ski, Warszawa 1980, s. 77.

${ }_{44}$ Літопис Самовидия..., s. 54.

${ }^{45}$ Ibidem, s. 52; Jawein Mecula..., s. 24.

${ }^{46}$ M.R. Drozdow ski, Jeremi Wiśniowiecki wobec Kozaczyzny [w:] Wobec króla i Rzeczypospolitej. Magnateria w XVI-XVIII wieku, red. E. Dubas-Urwan ow ic z, J. U rwan ow ic z, Kraków 2012, s. 708 . 
i więcej niebożąt, którzy stamtąd pouchodzili przybłąkało się do wojska naszego"47. Mając ograniczone możliwości bezpiecznego odwrotu, Wiśniowiecki ruszył w stronę Czernihowa, gdzie w końcu maja usiłował skłonić szlachtę zamkniętą w tamtejszym zamku do ucieczki pod osłoną jego oddziałów. Obrońcy, nie zdając sobie jeszcze sprawy z niebezpieczeństwa, odmówili, co przyszło im później przypłacić życiem ${ }^{48}$. Następnie, idąc przez Mozyr i Owrucz, Jarema dotarł do Żytomierza, gdzie otrzymał informację o Kozakach przebywających w należącym do jego synowców Niemiro$w^{4}{ }^{49}$. Pan na Łubniach i Wiśniowcu nie omieszkał wysłać miastu z odsieczą swoich chorągwi, akcja ta zakończyła się jednak niepowodzeniem ${ }^{50}$. Sam natomiast ruszył w tym czasie w kierunku swych włości na Wołyniu, ciągnąc za sobą rzesze Żydów, którzy przyłączali się doń w trakcie pochodu. Według Natana Hannowera wiódł on ze sobą 500 starozakonnych, nie licząc kobiet i dzieci, którzy dzięki książęcej eskorcie mogli kontynuować ucieczkę w głąb kraju lub szukać schronienia na Wołyniu ${ }^{51}$. Warto wspomnieć w tym miejscu, że część Żydów zaciągnęła się pod chorągwie księcia, aby walczyć z Zaporożcami ${ }^{52}$. Ponadto, jak dowodzą badania Zenona Guldona, wyznawcy religii mojżeszowej uciekali do twierdz i miast położonych w województwach podolskim, ruskim, bełskim czy ziemi chełmskiej. Część żydowskich uciekinierów przekraczała nawet Wisłę lub udawała się na Wołoszczyznę ${ }^{53}$.

Zajęcie licznych miast w województwie kijowskim, ogólne spustoszenie tego obszaru oraz wieści o okrucieństwach, jakie spadły na ludność cywilną, spowodowały, że rozpaczliwie poszukiwano dróg ucieczki przed Kozakami. Przypuszczalnie część osób wybierała kierunek północny, licząc na schronienie w litewskich twierdzach ${ }^{54}$. Szanse odnalezienia tam bezpiecznego azylu sugerowała polityka Chmielnickiego, który początkowo zabraniał atakowania majątków położonych na terenie Wielkiego Księstwa Litewskiego ${ }^{55}$. Zapewne nie chciał otwierać drugiego frontu przed opanowaniem sytuacji na Ukrainie, wkrótce jednak bunt przeniósł się również i na ten obszar $^{56}$. Źródła sugerują, że zdecydowana większość uchodźców kierowała się na zachód, do podolskich i wołyńskich warowni takich jak: Bar, Kamieniec Podolski,

${ }^{47}$ Pamiętniki Samuela i Bogusława Kazimierza Maskiewiczów (wiek XVII), oprac. A. Sajkow sk i, red. W. Czapliński, Wrocław 1961, s. 242-244.

48 Ibidem, s. 244.

49 Ibidem, s. 245-246.

${ }^{50}$ W. Maj e w s ki, Jeremi Wiśniowiecki w czerwcu - lipcu 1648 r. Cz. 1, „Rocznik Przemyski” 2007, t. 43 , z. 1 , s. $175-177$.

51 Jawein Mecula..., s. 22. Ze względu na kabalistyczny oraz propagandowy charakter kroniki Natana Hannowera należy podchodzić do podawanych w niej liczb z dużą ostrożnością. Nie ma jednak powodów, aby negować fakt, że pod osłoną armii Wiśniowieckiego wielu Żydów uciekło z Zadnieprza.

${ }_{52}$ М. Голін сь ки й, Silva Rerum (1648-1665), s. 141.

${ }^{53}$ Z. Guldon, Żydzi i Szkoci w Polsce w XVI-XVIII wieku. Studia i materiaty, Kielce 1990, s. 87.

${ }_{54}$ J.S. By stroń, Dzieje obyczajów w dawnej Polsce. Wiek XVI-XVII, t. 1, Warszawa 1994, s. 86.

55 Документи Богдана Хмельницького..., s. 58.

${ }_{56}$ Pamiętniki Filipa, Michała i Teodora Obuchowiczów (1630-1707), oprac. H. Lulewicz, A. Rachuba, red. A. Rachuba, Warszawa 2003, s. 230; W. Biern acki, Powstanie Chmielnickiego. Działania wojenne na Litwie w latach 1648-1649, Zabrze 2006, s. 17-19. 
Międzybórz czy Połonne ${ }^{57}$. Ucieczka za ich mury nie dawała jednak gwarancji bezpieczeństwa, powstanie bowiem szybko opanowało tę część kraju ${ }^{58}$.

Najpierw ucierpiało Podole, w połowie lipca buntownicy zdobyli bowiem Winnicę - główny ośrodek miejski województwa bracławskiego i miejsce odbywania sejmików tamtejszej szlachty ${ }^{59}$. Później padł Bar - dość słabo ufortyfikowane miasto z potężnym zamkiem warownym, którego obrony podjął się Andrzej Potocki, dowodzący oddziałem 200 dragonów królewicza Karola Ferdynanda Wazy ${ }^{60}$. Większość ludności pozostałej za murami stanowili Rusini, którzy naiwnie dali wiarę kozackim obietnicom o okazaniu łaski w przypadku otwarcia bram. Mołojcy wpuszczeni przez nich do miasta nie zamierzali dotrzymać danych gwarancji i rozpoczęli rzeź mieszkańców ${ }^{61}$. Według latopisu Samoiła Wieliczki oddziały Maksyma Krzywonosa zrabowały wówczas kosztowności należące do szlachty szukającej w Barze schronie$n^{6}{ }^{62}$. Informacja ta jest dosyć istotna, ponieważ stanowi dowód na to, że szlachta, umykając za bramy miast-twierdz, starała się ocalić nie tylko życie, ale także dobytek $^{63}$. Wobec przedostania się Kozaków za bramy Potocki znalazł się w beznadziejnej sytuacji, która zmusiła go do poddania zamku 8 sierpnia 1648 roku $^{64}$. Po upadku Baru na Podolu bronił się już tylko Kamieniec Podolski, o którym przypuszczano, że bez odsieczy rychło podzieli los innych warowni ${ }^{65}$.

Wołyńskie fortece również nie oparły się nawale buntowników. Międzyrzec trzykrotnie obronił się przed szturmem, ostatecznie jednak otworzono bramy mołojcom. Zaporożcy opanowali też Zasław, gdzie zbezczeszczono pochówki tamtejszych ksią$\dot{z} a ̨ c t^{66}$. Pod koniec lipca w wyniku zdrady obrońców padło Połonne na Wołyniu - potężna twierdza, która w założeniu miała dysponować zapasami pozwalającymi przetrwać nawet kilkumiesięczne oblężenie ${ }^{67}$. W rzezi miasta zginęło rzekomo 700 osób po stronie szlachty, nie licząc kobiet i dzieci, oraz 2000 Żydów ${ }^{68}$. Trudno zanegować informacje o srogim obejściu się buntowników z tamtejszą ludnością, liczby te

57 Джерела.., s. 463.

58 І.П. Кри п 'яке в и ч, Богдан Хмельницьький, ред. М.П. Парцей, Львів 1990, s. 87-88.

59 Джерела..., s. 92.

${ }^{60}$ Pamiętniki o wojnach kozackich za Chmielnickiego, wyd. Z. S chletter, Wrocław 1840, s. 19-20; W. Majews ki, Potocki Andrzej (Jędrzej) h. Pilawa (zm. 1663) [w:] Polski stownik biograficzny, t. 27, Wrocław-Warszawa-Kraków-1983, s. 770.

61 Документы об освободительной войне Украинского народа 1648-1654 г2., сост. А.З. Бар а бой, И.Л. Бутич, А.Н. Катренко, Е.С. Компан, Киев 1965, s. 99-100.

62 С. Величко, Літопис, т. 1, упор. В. Шевчук, Київ 1991, s. 89.

${ }^{63}$ Praktykę tę potwierdzają manifestacje oblatowane w księgach grodzkich na początku $1650 \mathrm{r}$. Manifestacja Zaszkowskich o zaginięcie munimentów, Центральний державний історичний архів України, м. Київ [dalej: ЦДІАУК], Ф. 11, оп. 1, спр. 13, k. 36v.

64 W. Majewski, Potocki Andrzej..., s. 770.

65 Jakuba Michałowskiego..., s. 154.

66 T. Józefowicz, Kronika miasta Lwowa..., s. 101.

${ }^{67}$ F. Si arczyńs k i, Obraz wieku panowania Zygmunta III króla polskiego i szwedzkiego, t. 2, Poznań 1858, s. 140.

68 Джерела..., s. 104. 
wydają się jednak znacznie zawyżone ${ }^{69}$. Nieco później padła także stolica województwa-Łuck - po zajęciu której rebelianci ruszyli pod Włodzimierz Wołyński i Sokal ${ }^{70}$. Liczni uciekinierzy z Połonnego i okolic szukali wobec tego schronienia, udając się w kierunku Brodów i Lwowa ${ }^{71}$. Do końca sierpnia siły Chmielnickiego opanowały niemal wszystkie większe miasta na Wołyniu ${ }^{72}$. Podobnie jak na Kijowszczyźnie ci, którzy nie opuścili na czas swoich siedzib, często tracili życie z ręki Zaporożców lub własnych poddanych. Ze szczególnym okrucieństwem traktowano przede wszystkim posesjonatów, których przed śmiercią starano się upokorzyć. Znany jest przypadek księcia Janusza Czetwertyńskiego, barbarzyńsko zamordowanego w Tulczynie przez poddanego mu młynarza. Nim magnatowi odcięto głowę toporem na progu, musiał on patrzeć na pohańbienie córki oraz żony, którą jeden z Kozaków następnie wziął w niewolę, przymuszając ją do gotowania mu strawy oraz oporządzania koni ${ }^{73}$.

Upadek kolejnych miast-twierdz spowodował, że zarówno miejscowa ludność, jak i gromadzący się w nich uciekinierzy zaczęli podejmować próby przedostania się do ośrodków położonych w głębi kraju. Według informacji posiadanych przez Adama Kisiela „wszystka Ukraina, kijowskie i bracławskie województwa, przed takowym gwałtem i potęgą nieprzyjacielską, rzucając domy i cara pignora sua zbiegli”, uchodząc między innymi do Ołyki, Dubna i Zamościa ${ }^{74}$. Wiadomo również o przypadkach osób, które pomimo niebezpieczeństwa pozostawały w swych włościach, „ale i tych Orda (gdy widać z miasteczek wychodzili) tak przywitała, że na wielu miejscach w pień wyścinali" 75 . Dopiero to doświadczenie sprawiło, że dotychczas odważni i uparci panowie bracia zaczęli myśleć o ucieczce. W konsekwencji tego po kilkunastu tygodniach od wybuchu powstania masy uchodźców z objętego nim obszaru zaczęły zalewać miasta w województwie lubelskim, co potęgowało strach przed kozackimi szablami i samopałami w centralnej części kraju ${ }^{76}$.

Zaporożcy po niechlubnej klęsce armii koronnej pod Piławcami, zgodnie z przewidywaniami, podeszli pod Brody, Lwów oraz Zamość. Pierwsze z tych miast

${ }^{69} \mathrm{Na}$ terenie Połonnego w 1620 r. znajdowało się zaledwie 14 szlacheckich dworów. W związku z powyższym trudno przypuszczać, że w chwili zajęcia miasta przez Kozaków przebywało w nim wielu herbowych, nawet zakładając, iż w jego murach schronili się panowie bracia uciekający przed Kozakami z południowego wschodu. I. Р ибачок, Соціальноекономічний розвиток міста Полонного в першій половини ст., „Наукові записки Національного університету »Острозька академія«. Серія: Історичні науки" 2009, вип. 14, s. 55-56. Informacja dotycząca pomordowanych Żydów wydaje się bardziej prawdopodobna, aczkolwiek wiadomo, że w Połonnem nie dokonano hekatomby wszystkich $\mathrm{z}$ obecnych tam wyznawców judaizmu, wielu z nich bowiem ocaliło życie, przyjmując chrzest. Jawein Mecula..., s. 38.

${ }^{70}$ Listy i zapiski Kazimierza Kuszewicza rajcy lwowskiego 1648-1657, Львівська національна наукова бібліотека України імені В. Стефаника, ф. 5, оп. 1, нр 2346, s. 24.

71 Джерела..., s. 97.

72 Jakuba Michałowskiego.., s. 176; Документы об освободительной войне.., s. 117.

73 Jakuba Michałowskiego..., s. 157; W.A. Serczyk, Na płonacej Ukrainie. Dzieje Kozaczyzny 1648-1651, Warszawa 2007, s. 118.

74 Jakuba Michałowskiego..., s. 65

${ }^{75}$ Ibidem, s. 65-66.

${ }^{76}$ E.A. Mierzwa, S. Tw orek, W okresie wojen i konfederacji 1569-1648 [w:] Dzieje Lubelszczyzny, t. 1, red. T. Mencel, Warszawa 1974, s. 358. 
zostało spalone, mołojcom nie udało się jednak zająć tamtejszego zamku, w którym schroniła się miejscowa ludność ${ }^{77}$. Pozostałe twierdze wytrzymały natomiast pierwszy impet kozacki i oblężenie, a następnie zapłaciły okup Chmielnickiemu za odstąpienie od murów ${ }^{78}$. Ze źródeł wynika, że uciekinierzy tłumnie przybywali do tych ośrodków, co nie może szczególnie dziwić, zważywszy na ich potencjał obronny. Pod tym względem wyróżniał się przede wszystkim Zamość, uchodzący za jedną z najsilniejszych twierdz w Rzeczypospolitej ${ }^{79}$. Trudno też nie doceniać Lwowa, który dowiódł w przeszłości, że może stanowić bezpieczny azyl ${ }^{80}$. Miasta te już w pierwszych tygodniach powstania Chmielnickiego zaczęły przygotowywać się do odparcia spodziewanego ataku. Ściągano do nich zapasy i amunicję oraz szkolono mieszczan do obrony murów ${ }^{81}$. Jak wynika z korespondencji Samuela Kuszewicza, ze względu na prokozackie postawy prawosławnej ludności uchodźców we Lwowie traktowano nieufnie czy nawet podejrzliwie. Zdając sobie sprawę z dotychczasowych przewag mołojców, mieszkańcy nie byli całkowicie pewni tego, że mury ich miast wytrzymają pod naporem szturmów. Przyczyną defetyzmu był zapewne upadek Połonnego, uważano bowiem, że skoro Zaporożcy zdołali zdobyć tak potężną twierdzę, niechybnie padnie także i stolica województwa ruskiego. Przykładowo podczaszy koronny, Mikołaj Ostroróg, polecił córce natychmiastowy wyjazd do centralnej części kraju. Lwów opuścił także arcybiskup Mikołaj Krosnowski oraz duża część duchowieństwa $^{82}$. Wiadomo również, że niektórzy próbowali uchodzić stamtąd na Węgry ${ }^{83}$. Brak wzmianek o ucieczkach z Zamościa może natomiast dowodzić pełnego przekonania jego mieszkańców o potencjale obronnym miasta.

Niniejszy szkic nie byłby pełny bez wspomnienia w nim o średniej i bogatej szlachcie zmuszonej do opuszczenia swych siedzib. Ta, według Filipa Kazimierza Obuchowicza, na wieść o przewagach Chmielnickiego „, W Wołynia, Kijowa, Bracławia, Podola na pował uciekła"84. Sejm elekcyjny, wychodząc naprzeciw potrzebom wynikającym ze specyfiki systemu funkcjonowania państwa, wyznaczył Warszawę na miejsce obrad sejmików relacyjnych dla województw: kijowskiego, ruskiego, wołyńskiego, podolskiego, bracławskiego i czernihowskiego ${ }^{85}$. Na sejmie koronacyjnym w 1649 roku postanowiono natomiast, że sejmik relacyjny i deputacki dla kijowian odbędzie się w Łucku, obywatele Bracławszczyzny zorganizują swoje zgromadzenia we Lwowie, szlachta czernihowska będzie zaś obradować w Lublinie ${ }^{86}$. Można

77 S. B arąc z, Wolne miasto handlowe Brody, Lwów 1865, s. 39-40.

78 L. Kubala, Oblężenie Lwowa w roku 1648, Kraków 1925, s. 18-28.

79 A.A. Witus i k, O Zamoyskich, Zamościu i Akademii Zamojskiej, Lublin 1978, s. 177; J. Ternes, Sejmik chetmski za Wazów 1587-1668, Lublin 2004, s. 72.

80 J. Tretiak, Historya wojny chocimskiej 1621 r., Lwów 1889, s. 38.

81 Документы об освободительной войне..., s. 76-77.

82 Kronika miasta Lwowa od roku 1634 do 1690..., s. 102.

83 Дожерела..., s. 419.

${ }^{84}$ Pamiętniki Filipa, Michała i Teodora Obuchowiczów..., s. 229; Latopisiec albo kroniczka..., s. 68; М. Гол ін с ь к й, Silva Rerum (1648-1665), s. 84-85.

85 J. S tolicki, Miejsca odbywania sejmików koronnych na wygnaniu w latach 1648-1696, ,Zeszyty Naukowe Uniwersytetu Jagiellońskiego. Prace Historyczne” 2017, nr 144, s. 442.

86 Ibidem, s. 443. 
więc zakładać, że część uciekinierów znalazła schronienie w pobliżu tych miast. Było to jednak rozwiązanie doraźne, docelowo bowiem panowie bracia zakładali powrót do swych siedzib po zaprzestaniu walk. W związku z tym warto zwrócić uwagę, że przedstawiciele elit posiadający dobra na obszarze ogarniętym powstaniem nie prezentowali jednolitego stanowiska w kwestii zakończenia buntu. Początkowo wielu z nich opowiadało się za zbrojną rozprawą z Kozakami, między innymi Jeremi Wiśniowiecki, Janusz Tyszkiewicz czy chorąży koronny Aleksander Koniecpolski. Przyczyną ich bezkompromisowej postawy była obawa przed utratą majątków, wpływów oraz upadkiem systemu polityczno-społecznego państwa ${ }^{87}$. Jednak im bliżej elekcji, tym większego politycznego znaczenia nabierała opinia w tej kwestii, przez co poglądy wielu zwolenników wojny ulegały złagodzeniu - zgodnie z linią stronnictwa królewicza Jana Kazimierza Wazy optującego za pokojowymi rozwiązaniami.

W ugodzie zborowskiej, kończącej pierwszy etap powstania z 1648 roku, nie określono w jednoznaczny sposób stanowiska w sprawie odzyskania przez szlachtę majątków na obszarze województw bracławskiego, kijowskiego i czernihowskiego. Niemniej, jak zwraca uwagę Michał Kulecki, zawarcie w niej punktu zakazującego trzymania Żydów w tamtejszych dobrach sugeruje, że Chmielnicki milcząco wyraził na to zgodę ${ }^{88}$. Panowie bracia nie zwlekali z powrotem do swych włości, urzędnicy zaś dość sprawnie wznowili działanie lokalnej administracji ${ }^{89}$. Nastroje były jednak dalekie od optymizmu, zdawano sobie bowiem sprawę z kruchości postanowień spod Zborowa i realnego niebezpieczeństwa ponownego wybuchu konfliktu. W anonimowym liście z lutego 1650 roku znajduje się wzmianka o tym, że na Kijowszczyźnie „szlachta w domach mieszka, lubo jeszcze jako goście" ${ }^{90}$. Reemigracja herbowych doprowadziła do dalszego narastania napięć na obszarze województw ukrainnych. Kozacy napadali na powracających panów braci oraz utrudniali działanie aparatu państwowego poprzez zakazywanie ludności uiszczania świadczeń poborcom ${ }^{91}$. Chłopi, których znaczna część uległa skozaczeniu, za wszelką cenę starali się uniknąc powrotu do odrabiania pańszczyzny ${ }^{92}$. Szlachta usiłowała natomiast mścić się za mordy i grabieże z minionych kilkunastu miesięcy ${ }^{93}$. W związku z powyższym ponowny wybuch konfliktu był kwestią czasu ${ }^{94}$.

Podsumowując, należy przyznać rację Józefowi Półćwiartkowi, który ocenił postępowanie Kozaków wobec cywilów w czasie powstania Chmielnickiego jako

${ }^{87}$ M.R. Drozdowski, My on nas i o innych..., s. 145-147.

${ }^{88}$ M. Kulecki, Wygnańcy ze Wschodu. Egzulanci w Rzeczypospolitej w ostatnich latach panowania Jana Kazimierza i za panowania Michała Korybuta Wiśniowieckiego, Warszawa 1997, s. 169.

${ }^{89}$ Dla przykładu 5 XII 1649 r. działalność wznowił sąd grodzki w Żytomierzu. ЦДІАУК, Ф. 11, оп. 1, спр. 13, k. 1; Manifestacja Jana Czarnockiego, ibidem, k. 1v.

90 Джерела..., т. 2: (1650-1651 pp.), упор. Ю. Мици к, Київ 2013, s. 13.

${ }^{91}$ D. Ku p i s z, Próby organizacji wojsk ,obrony domowej” " przez szlachtę województw kijowskiego, bractawskiego i czernihowskiego (1649-1650), „Kwartalnik Historyczny”, R. 125, 2018 , z. 1, s. 22.

${ }^{92}$ M. Kulecki, op. cit., s. 170.

${ }_{93}$ Z. Wójcik, Dzikie pola w ogniu. O Kozaczyźnie w dawnej Rzeczypospolitej, Warszawa 1968, s. 184 .

${ }_{94}$ M. Kulecki, op. cit., s. 170. 
przykład rzadko spotykanego barbarzyństwa ${ }^{95}$. Ich działania dotykały różnych grup ludności, niemniej podczas buntu ze szczególnym okrucieństwem traktowano przede wszystkim szlachtę i chłopów wyznania katolickiego oraz Żydów. Wynikało to z charakteru rebelii, która przybrała formę walki o likwidację istniejącego ładu społeczno-ekonomicznego, obronę cerkwi, a z czasem także stworzenie niezależnego organizmu państwowego ${ }^{96}$. Ludność dotknięta powstaniem szukała schronienia przede wszystkim w ośrodkach miejskich, których mury stwarzały pozory bezpieczeństwa. W przypadku ich kapitulacji ocaleni podejmowali dalsze próby przedostania się do miast-twierdz położonych $\mathrm{w}$ głębi kraju. Warto $\mathrm{w}$ tym miejscu zaznaczyć, że tendencja ta zmieniała się w miarę rozwoju rebelii, w jej późniejszym etapie chłopi zaczęli bowiem upatrywać ratunku w zbiegostwie na teren Państwa Moskiewskiego ${ }^{97}$. Liczne przypadki poddawania miejsc warownych bez walki dowodzą, że istotny wpływ na skuteczność obrony miał skład społeczny ich załóg, które po ucieczce szlachty składały się głównie z Rusinów ${ }^{98}$.

Trudno oszacować liczbę uciekinierów z południowo-wschodnich województw Rzeczypospolitej podczas powstania Chmielnickiego oraz pomordowanych w wyniku działań kozackich. W literaturze można odnaleźć szacunki, że w latach 16481654 zginęło nawet około 100-125 tys. Żydów ${ }^{99}$. Najbardziej realne w tej kwestii są jednak ustalenia Shaula Stampfera, według którego ofiarą mołojców padło maksymalnie 18-20 tys. starozakonnych, którzy stanowili około 50\% populacji Żydów na terenie objętym powstaniem ${ }^{100}$. Twierdzi on przy tym, że około 8 tys. wyznawców judaizmu ocalało dzięki ucieczce ${ }^{101}$. Aby przedstawić podobne wyliczenia dla chło-

95 J. Półćwiartek, Najdalszy zachodni pochód wojsk Bohdana Chmielnickiego - mit a rzeczywistość [w:] Козацькі війни XVII століття в історичній свіомості польського та українського народів. Матеріали Другої Польсько-Української Наукової Зустрічі (Львів, 12-13 жовтня 1995 р.), за ред. Л. З ашкі льн я ка, Львів-Люблін 1996, s. 85.

96 F.E. Sys yn, The Khmel'nyts 'kyi Uprising: A Characterization of the Ukrainian Revolt, „Jewish History" 2003, vol. 17, no. 1, s. 130.

97 Акты относящиеся к истории Южной и Западной России..., s. 225.

98 S. Twardow ski, Woyna domowa z Kozaki i Tatary Moskwa, potym Szwedami, i z Węry Przez lat Dwanascie Za Panowania Nayjasnieyszego Iana Kazimierza Krola Polskiego toczaca się, Kalisz 1681, s. 19, 24.

${ }_{99}$ M. Ho rn, Żydowskie bractwa rzemieślnicze na ziemiach polskich, litewskich, białoruskich $i$ ukraińskich $w$ latach 1613-1850, Warszawa 1998, s. 27. Według żydowskich kronik liczba Żydów, którzy zginęli podczas kozackiego buntu, waha się od 121 tys. do 180 tys. Wyjątkiem jest dzieło Tit Ha-Yeven Samuela Feibisha, syna Natana Feitela z Wiednia, który utrzymywał, że w pierwszych dwóch latach kozackiego buntu miało zginąć aż 670 tys. wyznawców Jahwe. T. Ci e si els ki, The Jews in Times of War and the Social and Political Riots in the Southeast of the Polish-Lithuanian Commonwealth in the 17th and $18^{\text {th }}$ Centuries, „Biuletyn Polskiej Misji Historycznej” 2014, nr 9, s. 273. Szczególnie ostatnia z liczb jest znacznie zawyżona, wystarczy bowiem wspomnieć, że według ustaleń Ignacego Schipera w przededniu powstania Chmielnickiego Rzeczpospolitą zamieszkiwało ok. 450 tys. Żydów. I. S chi per, $\dot{Z} y d z i$ w dawnej Rzeczypospolitej Polskiej [w:] Żydzi w Polsce odrodzonej..., s. 31.

100 S. S ta m p fer, What Actually Happened to the Jews of Ukraine in 1648?, „Jewish History”2003, vol. 17 , no. 1 , s. 221.

101 Ibidem, s. 218. Wielu Żydów przedostało się w głąb Korony, o czym świadczy ich masowy napływ do miast w centrum Rzeczypospolitej. Wzrost liczebności starozakonnych jest dobrze widoczny, chociażby w miastach położonych na Podkarpaciu. T. Jaworski, Wojna pokój i religia a ruchy lud- 
pów i szlachty, należałoby przeprowadzić szczegółowe badania, niemniej zważywszy na zaludnienie województw ukrainnych można przypuszczać, że liczby te byłyby znacznie wyższe ${ }^{102}$.

\section{BIBLIOGRAFIA}

\section{Źródła rękopiśmienne}

Львівська національна наукова бібліотека України імені В. Стефаника ф. 5, оп. 1, нр 2346

Центральний державний історичний архів України, м. Київ ф. 11 , оп. 1 , спр. 13

\section{Źródła drukowane}

Jakuba Michałowskiego wojskiego lubelskiego a później kasztelana bieckiego księga pamiętnicza, wyd. A.Z. Helc el, Kraków 1864.

Jawein Mecula, t.j. Bagno głębokie, kronika zdarzeń z lat 1648-1652 napisana przez Natana Hannowera z Zastawia $i$ wydana po raz pierwszy $w$ Wenecyi $w r$. 1656, oprac. M. B ałab a n [w:] Sprawy i rzeczy ukraińskie. Materyały do dziejów kozaczyzny i hajdamaczyzny, wyd. F. Rawita-Gawroński, Lwów 1914, s. 1-76.

J e mi ołow ski M., Pamiętnik dzieje Polski zawierający (1648-1679), oprac. J. D zi ęgi elew ski, Warszawa 2000.

Józe fowicz T., Kronika miasta Lwowa od roku 1634 do 1690 obejmująca w ogólności dzieje dawnej Rusi Czerwonej a zwłaszcza historya arcybiskupstwa lwowskiego w tejże epoce, wyd. M. Piw ocki, Lwów 1854.

K o c h o w s k i W., Annalium Poloniae ab obitu Vladislai IV. Climacter Primus, Cracoviae 1683. Latopisiec albo kroniczka Joachima Jerlicza, wyd. K.W. W ó j c i c ki, Warszawa 1853.

Pamiętniki Filipa, Michała i Teodora Obuchowiczów (1630-1707), oprac. H. Lulewicz, A. R a chuba, red. A. Ra chuba, Warszawa 2003.

Pamiętniki o wojnach kozackich za Chmielnickiego, wyd. Z. Schletter, Wrocław 1840.

Pamiętniki Samuela i Bogusława Kazimierza Maskiewiczów (wiek XVII), oprac. A. Sajkowski, red. W. Czapliński, Wrocław 1961.

Twardowski S., Woyna domowa z Kozaki i Tatary Moskwa, potym Szwedami, i z Wegry Przez lat Dwanascie Za Panowania Nayjasnieyszego Iana Kazimierza Krola Polskiego toczaca się, Kalisz 1681.

nościowe na polskim pograniczu zachodnim w XVII i na początku XVIII w., Zielona Góra 1998, s. 132. M. Gosztyła, M. Proks a, Kirkuty Podkarpacia, Przemyśl 2001, s. 68.

${ }_{102}$ Z. Guldon, Badania nad zaludnieniem Ukrainy w XVII wieku, „Kwartalnik Historii Kultury Materialnej” 1965, t. 13, nr 3, s. 561-566; Н.М. Яко в ен ко, Спроба обрахунку чисельності шляхти на правобережній Україні у першій половині XVII cm. [w:] Украӥна і Польщза в період феодалізму. Збірник наукових праиьь, відп. ред. В.А. См олі й, Київ 1991, s. 86-97. 
Ukraina $w$ połowie XVII wieku $w$ relacji arabskiego podróżnika Pawła, syna Makarego z Aleppo, wyd. M. Kow als k a, Warszawa 1986.

Volumina Constitutionum, t. 3: 1611-1640, vol. 2: 1627-1640, wyd. S. Grodziski, M. Kwi ecień, A. Karabowicz, Warszawa 2013.

Акты, относящиеся к истории Южной и Западной России, собранные и изданные Археографическою комиссиею, т. 3: 1638-1657, ред. Г.Ф. К а р п о в, Санктпетербург 1861.

В ел и ч к С., Літопис, т. 1, упор. В. Ш е вчук, Київ 1991.

Воссоединение Украины с Россией. Документы и материаль в трех томах, т. 2: Освободительная война украинского народа и борьба за воссоединение с Россией 1648-1651 годы, сост. П.П. Гузен но, М.К. Козыренко, А.П. Лола, И.Л. Бутич, М.Г. Р епецкая, Москва 1953.

Голінський M., Silva Rerum (1648-1665), ч. 1: (1648-1649), упор. О. Заяць, Я. Фед орук, Київ 2019.

Джерела з історії Національно-визвольної війни українського народу 1648-1658 рр., т. 1-2, упор. Ю. М иц и к, Київ 2012-2013.

Документи Богдана Хмельнищького 1648-1657, упор. І. Кр и п я ке в и ч, І. Бут ич, Київ 1961.

Документы об освободительной войне Украинского народа 1648-1654 г2., сост. А.З. Барабой, И.Л. Бутич, А.Н. Катренко, Е.С. Компан, Киев 1965.

Літопис Самовидия, підг. Я.І. Дз и ра, Київ 1971.

Материяли до істориї Галичини, т. 2: Акти з р. 1649-1651, упор. С. Томаш ів сь к й, Лвов 1901.

\section{Opracowania}

B arąc z S., Wolne miasto handlowe Brody, Lwów 1865.

B auer M., Mikołaj Jemiołowski: Historyk czy pamiętnikarz? O literackości pamiętnika z czasów wojen drugiej połowy XVII wieku, „Acta Universitatis Lodzensis. Folia Litteraria Polonica" 2006, t. 8, s. 87-106.

Biernacki W., Powstanie Chmielnickiego. Działania wojenne na Litwie w latach 1648 1649, Zabrze 2006.

B iernacki W., Żótte Wody-Korsuń 1648, Warszawa 2004.

Borowiak A., Kozaczyzna w przededniu powstania Bohdana Chmielnickiego (16351648) [w:] Epoka „, Ogniem i mieczem” we współczesnych badaniach historycznych, red. M. Nagielski, Warszawa 2000, s. 25-44.

Bystroń J.S., Dzieje obyczajów w dawnej Polsce. Wiek XVI-XVII, t. 1, Warszawa 1994.

Chynczew ska-Hennel T., Świadomość narodowa szlachty ukraińskiej i Kozaczyzny od schyłku XVI do połowy XVII w., Warszawa 1985.

Cies i elski T., The Jews in Times of War and the Social and Political Riots in the Southeast of the Polish-Lithuanian Commonwealth in the $17^{\text {th }}$ and $18^{\text {th }}$ Centuries, ,Biuletyn Polskiej Misji Historycznej" 2014, nr 9, s. 267-290.

Cieśla M., Żydzi a Rzeczpospolita [w:] My i oni. Społeczeństwo nowożytnej Rzeczypospolitej wobec państwa, red. W. Kri e g s e is e n, Warszawa 2016, s. 259-285.

Drozdowski M.R., „, Co za czasy!... Chamy taki miód pija!! Boże, Ty to widzisz i nie grzmisz?". O deprecjacji Kozaków przez szlachtę Rzeczypospolitej w okresie powstania Chmielnickiego, „Annales Universitatis Mariae Curie-Skłodowska Lublin - Polonia. Sectio F" 2018, vol. 78, s. 65-82.

Drozdows ki M.R., Jeremi Wiśniowiecki wobec Kozaczyzny [w:] Wobec króla i Rzeczypo- 
spolitej. Magnateria w XVI-XVIII wieku, red. E. Duba s - Urwan ow i c z, J. Urwanowic z, Kraków 2012, s. 703-716.

Drozdowski M.R., My o nas $i$ o innych. Szlachta Rzeczypospolitej wobec Kozaczyzny zaporoskiej w latach 1648-1659, Białystok 2018.

Drozdows ki M.R., Religia i Kozaczyzna zaporoska w Rzeczypospolitej w pierwszej połowie XVII wieku, Warszawa 2008.

Gavryliuk I., Niewygrana wojna. Sztuka wojenna Bohdana Chmielnickiego i innych dowódców kozackich w latach 1648-1651, Oświęcim 2019.

Gosztyła M., Proks a M., Kirkuty Podkarpacia, Przemyśl 2001.

Guld on Z., Badania nad zaludnieniem Ukrainy w XVII wieku, „Kwartalnik Historii Kultury Materialnej” 1965, t. 13, nr 3, s. 561-566.

Guldon Z., Żydzi i Szkoci w Polsce w XVI-XVIII wieku. Studia i materiaty, Kielce 1990.

Horn M., Żydowskie bractwa rzemieślnicze na ziemiach polskich, litewskich, białoruskich i ukraińskich w latach 1613-1850, Warszawa 1998.

J a w or ski T., Wojna, pokój i religia a ruchy ludnościowe na polskim pograniczu zachodnim w XVII i na poczatku XVIII w., Zielona Góra 1998.

Kaczmarczyk J., Bohdan Chmielnicki, Wrocław-Warszawa-Kraków 1988.

Kocój E., Świątynie, postacie, ikony. Malowane cerkwie i monastyry Bukowiny Poludniowej w wyobrażeniach rumuńskich, Kraków 2006.

Ku charski W., Rozbicie armii koronnej $w$ działaniach wojennych 1648 r., „Studia z Dziejów Wojskowości” 2015, t. 4, s. 57-99.

Kulecki M., Wygnańcy ze Wschodu. Egzulanci w Rzeczypospolitej w ostatnich latach panowania Jana Kazimierza i za panowania Michała Korybuta Wiśniowieckiego, Warszawa 1997.

Kupisz D., Próby organizacji wojsk ,obrony domowej” przez szlachte województw kijowskiego, bracławskiego i czernihowskiego (1649-1650), „Kwartalnik Historyczny”, R. 125, 2018 , z. 1, s. 5-27.

Li i ińs ki W., Stanisław Michał Krzyczewski. Z dziejów walki szlachty ukraińskiej w szeregach powstańczych pod wodza Bohdana Chmielnickiego, Kraków 1912.

Litw in H., Napływ szlachty polskiej na Ukraine 1569-1648, Warszawa 2000.

Łopatecki K., Disciplina militaris $w$ wojskach Rzeczypospolitej do połowy XVII wieku, Białystok 2012.

Majewski W., Jeremi Wiśniowiecki w czerwcu - lipcu 1648 r. Cz. 1, „Rocznik Przemyski” 2007, t. 43, z. 1, s. 169-186.

Majewski W., Potocki Andrzej (Jędrzej) h. Pilawa (zm. 1663) [w:] Polski stownik biograficzny, t. 27, Wrocław-Warszawa-Kraków 1983, s. 770-773.

Mierzw a E.A., Tw orek S., Wokresie wojen i konfederacji 1569-1648 [w:] Dzieje Lubelszczyzny, t. 1, red. T. Mencel, Warszawa 1974, s. 353-392.

Nagielski M., Ukraińcy [w:] Pod wspólnym niebem. Narody dawnej Rzeczypospolitej, red. M. Kopczyński, W. Tygielski, Warszawa 2010, s. 55-78.

Pernal A.B., Rzeczpospolita Obojga Narodów a Ukraina. Stosunki dyplomatyczne w latach 1648-1659, tłum. R. Urbański, Kraków 2010.

Półćwiartek J., Najdalszy zachodni pochód wojsk Bohdana Chmielnickiego - mit a rzeczywistość [w:] Козацькі війни XVII століття в історичній свіомості польського та українського народів. Матеріали Другої Польсько-Української Наукової Зустрічі (Львів, 12-13 жовтня 1995 р.), за ред. Л. Зашкільняка, Львів-Люблін 1996, s. 76-90.

Ringelblum E., Dzieje zewnętrzne Żydów w dawnej Rzeczypospolitej [w:] Żydzi w Polsce odrodzonej. Działalność społeczna, gospodarcza, oświatowa i kulturalna, t. 1, red. I. Schiper, A. Tartakower, A. Hafftka, Warszawa 1932, s. 37-80. 
Rolle A.J., Żydzi na kresach, „Przewodnik Naukowy i Literacki. Dodatek do Gazety Lwowskiej” 1877, R. 5, s. 34-45.

Schall J., Rok 1648 i kniaź Jeremi Wiśniowiecki w świetle współczesnych historyków żydowskich, „Miesięcznik Żydowski”, R. 4, 1934, s. 264-268.

Schiper I., Żydzi w dawnej Rzeczypospolitej Polskiej [w:] Żydzi w Polsce odrodzonej. Działalność społeczna, gospodarcza, oświatowa i kulturalna, t. 1, red. I. Schiper, A. Tartakower, A. Hafftka, Warszawa 1932, s. 21-36.

Serczyk W.A., Na płonacej Ukrainie. Dzieje Kozaczyzny 1648-1651, Warszawa 2007.

S i a c zyńs k i F., Obraz wieku panowania Zygmunta III króla polskiego i szwedzkiego, t. 2, Poznań 1858.

S tampfer S., What Actually Happened to the Jews of Ukraine in 1648?, „Jewish History” 2003, vol. 17, no. 1, s. 207-227.

Stolicki J., Miejsca odbywania sejmików koronnych na wygnaniu w latach 1648-1696, „Zeszyty Naukowe Uniwersytetu Jagiellońskiego. Prace Historyczne” 2017, nr 144, s. 441-457.

S vo boda L., Vztahy Bohdana Chmelnického a Moskvy v letech 1648-1649, „Sborník Prací Filozofické Fakulty Brnénské Univerzity. Studia Minora Facultatis Philosophicae Universitatis Brunensis" 2001, C 48, s. 119-143.

Sysyn F.E., The Khmel'nyts'kyi Uprising: A Characterization of the Ukrainian Revolt, „Jewish History” 2003, vol. 17, no. 1, s. 115-139.

Ternes J., Sejmik chetmski za Wazów 1587-1668, Lublin 2004.

Tomkiewicz W., Kozaczyzna ukrainna, Lwów 1939.

Tomkiewicz W., Ograniczenie swobód kozackich w roku 1638, „Kwartalnik Historyczny" 1930 , R. 44, t. 1, z. 2, s. 125-175.

Tretiak J., Historya wojny chocimskiej 1621 r., Lwów 1889.

Witusik A.A., O Zamoyskich, Zamościu i Akademii Zamojskiej, Lublin 1978.

Wój cik Z., Dyplomacja polska w okresie wojen drugiej połowy XVII wieku (1648-1699) [w:] Historia dyplomacji polskiej, t: 2: 1572-1795, red. Z. Wój cik, Warszawa 1982, s. $163-330$.

Wójcik Z., Dzikie pola w ogniu. O Kozaczyźnie w dawnej Rzeczypospolitej, Warszawa 1968.

Брехуненко В., Богдан Хмельницький, Київ 2007.

Кр ип'якевич І.П., Богдан Хмельницький, ред. М.П. Парце й, Львів 1990.

Р и бачок І., Соціальноекономічний розвиток міста Полонного в першій половини ст., „Наукові записки Національного університету »Острозька академія«. Серія: Історичні науки" 2009, вип. 14, s. 48-59.

Смолій В.А., С тепан ко в В.С., Богдан Хмельницький, Київ 2013.

Смолій B.А., Степанков В.С., Украӥнська державна ідея XVII-XVIII століть: Проблеми формування, еволюиії, реалізації, Київ 1997.

Федорук Я., Зовнішньополітична діяльність Богдана Хмельницького і формування його політичної програми (1648 - серпень 1649 рр.), Львів 1993.

Щербак В.О., Антифеодальні рухи на Україні напередодні визвольної війни 1648-1654 рр., Київ 1989.

Яковенко Н.М., Спроба обрахунку чисельності иляхти на правобережній Україні y першій половині XVII cm. [w:] Україна і Польща в період феодалізму. Збірник наукових праць, відп. ред. В.А. С м ол і й, Київ 1991, s. 86-97. 
